\title{
At the intersection of materiality, organizational legitimacy and institutional logics:
}

\author{
A study of campus tours ${ }^{1}$
}

François-Xavier DE VAUJANY

Dauphine Recherche en Management (DRM), PSL-Université Paris-Dauphine, France

Sara WINTERSTORM VARLANDER

Center for Work, Technology and Organization, Stanford University, USA

Emmanuelle VAAST

Desautels Faculty of Management, McGill University, Canada

\footnotetext{
${ }^{1}$ Earlier drafts of this chapter were presented APROS in December 2015, the 4th Organizations, Artifacts and Practices (OAP) workshop in June 2014 and the Workshop "Giving visual and material form to ideas, identity and imagination: architecture, urbanism and sustainable construction" in May 2014. We thank all participants for their precious feedbacks and comments.
} 


\section{Introduction}

During the last decade or so, the phenomenon of campus tours, also called 'the Golden Walk' (Hoover, 2009, 2010; Miller, 2012) has become increasingly widespread, particularly among U.S. universities, as they have been considered an effective student recruitment practice. Facing tightened budgets, universities have had to expand their recruitment efforts to generate substantial applicant pools (Padjen, 2002). Furthermore, higher education has often been labeled as a business, selling intangible products to students, who are increasingly wary of debt and consumer savvy (Padjen, 2002; Washburn \& Petroshius, 2004), and who consider multiple factors in their choice of college or university. Thus, universities today are facing conflicting demands and pressures, dictated by various institutional logics (Jarzabkowski et al. 2013; Greenwood et al. 2010). On one hand, the industry or market logic prescribes business-like practices and goals. On the other hand, the social logic dictates values such as individual learning and the cultivation of the citizens (Gumport, 2000; Carnoy and Rhoten, 2002; Kondakci and Van den Broeck, 2009).

In this complex and changing institutional context, it is crucial for universities to acquire and maintain their legitimacy (e.g. Meyer and Rowan 1977; DiMaggio and Powell 1983; Elsbach 1994; Scott 1995; Lounsbury and Glynn 2001; Suddaby and Greenwood 2005). Building legitimacy is imperative for organizations to be perceived as "more meaningful, more predictable, and more trustworthy" (Suchman, 1995, p. 575) and to receive more support and resources from external stakeholders (Ashforth and Gibbs, 1990). To sustain legitimacy, organizations may rely on different broad modalities of justification, or institutional logics that can dictate various goals and subsequent practices of legitimation.

Thus far, while studies have explored how institutional logics are invoked in symbolic management practices when firms compete for resources (Jones, Livne-Tarandach, and 
Balachnadra, 2010), very few have studied how institutional logics are instantiated in the material context of organizations (Jones, Boxenbaum, and Anthony, 2013). In order to start addressing this gap in the literature, here we argue that campus tours constitute a particular, walking-based, practice that is simultaneously discursive, material, visual and embodied (de Certeau, 1980, Schatzki, 2001, Rose and Tolia Kelly, 2012; de Vaujany and Vaast, 2016), and that aims at establishing legitimacy by invoking the material context of the university in its legitimacy claims. Through the lens of de Certeau (1980) and his attention to walking as a particular practice that 'makes space talk', we address how materiality, through the practice of walking, is involved in symbolic management that aims at promoting an adherence to diverse, conflicting institutional logics. Specifically, our research question reads: How do the walking practices of campus tours invoke materiality to make legitimacy claims?

The organization of the paper is as follows. We first introduce key issues related to organizational legitimation, followed by an introduction of our lens of walking as a practice in which space is made alive and invoked in legitimacy claims. We then outline the method we employed before presenting our findings and resulting propositions related to how institutional logics are enacted in legitimation practices and the role of materiality therein. We conclude with a summary of this work's contributions, limitations, and promising future research avenues.

\section{Organizational legitimation}

How organizations acquire and maintain their legitimacy in complex and changing institutional contexts has been a significant topic in institutional theory (e.g. Meyer and Rowan 1977; DiMaggio and Powell 1983; Elsbach 1994; Scott 1995; Lounsbury and Glynn 2001; Suddaby and Greenwood 2005). Organizational legitimacy corresponds to "a 
generalized perception or assumption that the actions of an entity are desirable, proper, or appropriate within some socially constructed system of norms, values, beliefs, and definitions" (Suchman, 1995, p. 574). The process of legitimation is essential for organizations to gain support and resources from multiple stakeholders (Ashforth and Gibbs, 1990).

Organizations can pursue legitimacy in various ways (Ashford and Gibbs, 1990; Oliver, 1991; Suchman, 1995). Ashforth and Gibbs (1990) consider that organizations may resort to substantive or symbolic management in their legitimation efforts. In this paper, the focus lies on symbolic management that implies that an organization may change the ways in which it portrays itself to appear more consistent with stakeholders' expectations. As the number of organizational relationships tend to grow and organizational fields become more complex (Kraatz and Block, 2008), it becomes impossible for each and every stakeholder to have deep substantial knowledge about an organization, which explains why symbolic management has become increasingly strategic to organizations. Also, managers may resort to symbolic management since it does not require any substantial changes of the underlying processes and infrastructure of the organization, but rather involves control over, and creativity with, the resources at hand. Thus, in contrast to substantive management, which implies that organizations try to create real, material change in their goals, structures and processes, or in alterations of socially institutionalized practices (such as role performance and coercive isomorphism), symbolic management does not involve specific material changes in the ways organizations operate. However, materiality (in particular that of communication practices themselves) still remains important in symbolic management, which we argue can be tightly and powerfully connected to - and amplified by - the material context of the organization. The materiality of an organization (e.g. buildings, statues, technologies, facilities, pieces of art, morphology of the area, etc.) is thus selected, visualized or incorporated into organizational 
narratives by means of specific communication practices, where the walked campus tours are central.

Organizations engage in symbolic management when they try to espouse socially acceptable goals, while actually pursuing less acceptable ones. One example would be organizations that espouse ethics policies without actually implementing processes for monitoring compliance with those policies. Organizations deploy various symbolic management strategies. For instance, through denial and concealment, some organizations may attempt to hide information about their activities or outcomes that would risk undermining their legitimacy. Organizations may also attempt to redefine their means and ends. Since legitimation is mainly a retrospective process, an organization has the freedom to interpret and account for how its past is aligned with current social values (Maclean, Harvey, and Chia, 2012). Closely related to this are the implications that removing the organization from a situation may negatively impact its image or claim to legitimacy. Finally, ceremonial conformity implies that an organization may claim legitimacy by adopting certain highly visible and salient practices aligned with social expectations, while not changing the underlying infrastructure of the organization. These practices are adopted solely for their symbolic value.

Organizations engage in symbolic legitimation efforts depending on whether the organization faces a need to extend, maintain or defend its legitimacy (Ashforth and Gibbs, 1990). Our research focuses on legitimation claims aiming at maintaining legitimacy, which is the case when organizations have "attained a threshold of endorsement sufficient for ongoing activity" (Ashforth and Gibbs, 1990, p. 183). To maintain their legitimacy, legitimation efforts especially entail symbolic management-related activities.

The literature on organizational impressions and symbolic management (see, e.g., Elsbach 1994) considers that organizational members, and specifically managers, are instrumental in 
their communications as they signal the appropriateness and effectiveness of organizational activities to internal and external stakeholders (Golant and Sillince, 2007). In this paper, we follow this tenet and adopt a practice lens that highlights, in a fine-grained way, how walked campus tours are instrumental for universities to make legitimacy claims and how tours constitute a clear illustration that shed light on the intertwining of the institutional and material dimensions involved in legitimation. More specifically, drawing on de Certeau (1980; 1984) we delve into the practice of walking and movement to understand this intertwining.

\section{A practice-based, mobile view of legitimation process}

In this paper we view legitimation and campus tours as a 'practice', which implies that we are interested in "the fine details of how people use the resources available to them to accomplish intelligent actions, and how they give those actions sense and meaning" (Gherardi, 2012, p.2).

There are several important differences between practice theories and other theories of a social nature. One key difference is that what is thought of as the creation of shared meanings is argued to be created not in the human mind, as mentalists would argue (e.g. classical structuralism and interpretivism); nor is it located in symbolic interactions (e.g. theory of communicative action, symbolic interactionism); or as post-modernists would claim, in 'texts' (e.g. post-structuralism and various forms of post-modernism). Instead, practice theory argues that meaning is created in 'practices', which implies that the loci in focus include the body, cognition, things, knowledge, language/discourse, structure/process and human agency and their embeddedness in practice (Bourdieu, 1972; de Certeau, 1980; Giddens, 1984; Sandberg and Dall'Alba, 2009).

Put simply, "practices are loci - spatial and temporal - in which working, organizing, innovating or reproducing occurs" (Gherardi, 2012, p.2) and are "embodied, materially 
mediated arrays of human activity centrally organized around shared practical understanding" (Schatzki, 2001: 2). Hence, activity is the central element of practice; and it is the set of activities that form a pattern that makes a practice (Gherardi, 2012). The activities are composed of humans and non-humans, sayings and doings, and there is not a privileged place for any of these elements, but rather, they are seen as intertwined. Thus, practice theorists aim to go beyond problematic dualisms (de Certeau, 1980; Reckwitz, 2002), for example, between mind and body or human and material (Gherardi, 2012). Recent work in a post-humanist vein has been strongly influencing practice theory (Schatzki, 2001); and science and technology scholars such as Latour (1987, 2005), Callon (1986), Knorr-Cetina (1997), Pickering and King (1995), Pinch (2008) and Suchman (2007) have articulated, albeit in different ways, the role of non-humans, such as technology, buildings and artifacts, in the production and reproduction of social life (Feldman and Orlikowski, 2011).

Thus, this implies that practice theorists attribute an important role not only to humans, but also to non-humans such as artifacts, technology and space. In this paper, we take this lens to practices as we are particularly interested in understanding practices as extending beyond humans and including the contexts, spaces and places in which humans act and interact. De Certeau (1984), a major source of practice-based studies, has acknowledged space as central to practice through his example of walking in the space of a city, where he shows how the practice of walking creates the link between the morphology of space and practice. On the one hand, he argues that when walking in a space, there are the expected behaviors that a space will dictate (e.g. crossing a street at the crosswalk, walking on the pavement and not the street itself, sitting on a bench in a park). On the other hand, there is the instantiation of the space through 'speech acts', where space is incorporated into a narrative, particular artifacts are pointed out and commented on, etc. This later process can be creative in the sense that people can circumvent expected behaviors and produce new or unexpected relationships with the 
space. For de Certeau, it is through the practice of walking that the city 'expresses itself' as a space and its meaning is created. There is not one particular meaning of a space, but rather it is through walking that various meanings are created that can circumvent, reduce, extend or divert 'the grammar' of space. Thus, through the practice of walking, space can take on a variety of different meanings. The walking practice of a campus tour hence becomes one of many possible ways of experiencing a campus and of making legitimacy claims.

Building upon Augoyard (1979), de Certeau (1980) argues that the practice of walking in space combines two stylistic figures: the synecdoche and the asyndeton. In a synecdoche, a word is employed "in a sense which is part of another meaning of the same word." In short, "it names a part instead of the whole which includes it" (de Certeau, 1984, p. 101). Thus, a synecdoche "expands a spatial element in order to make it play the role of "more" (Ibid, p. 101). For example, a bicycle or a piece of furniture in a shop window stands for the whole street or neighborhood. It "replaces totalities by fragments", "amplifies the detail and miniaturizes the whole" (p. 101). The asyndeton accomplishes the reverse. Instead of amplifying details and making broad claims based on fragments, an asyndeton skips, omits and neglects spaces traversed. It is a strategy of 'cutting out' and it undoes continuity by creating "less" and "open gaps in the spatial continuum" (p. 101). In short, through these stylistic figures, some parts of space disappear while others are exaggerated, distorting and fragmenting the space and making it something that invokes different logics. Through the lens of these pedestrian figures, in the empirical context of universities, the walked campus tour makes legitimacy claims that are creatively crafted (invoking different logics) that make sense through walking and that are linked to the spatial context of the organization. Thus, as we build upon de Certeau's lens of walking, we also adhere to Jarzabkowski et al.'s (2007, p. 6) mandate that "micro-phenomena (...) be understood in their wider social context" and claim 
that "actors are not acting in isolation but are drawing upon the regular, socially defined modes of acting that arise from the plural social institutions to which they belong."

In this paper, we argue that a practice lens inspired by de Certeau and his focus on movement will extend this initial understanding of the role of materiality in institutional theory. A focus on practices, and movement in space in particular, will yield an understanding not only of the rhetoric dictated by logics, but also how material artifacts are invoked in legitimacy claims to subscribe to or take distance from particular logics.

\section{Method}

\section{Empirical settings}

Our empirical inquiry focuses on a context where the relationships between practices, materiality and legitimacy are most vividly at stake: university campus tours.

The notion of campuses has a long history and originates from the US (Turner, 1984; Scotto, 2014). Basically, "the word campus, more than any other term, sums up the unique physical character of the American college and university [...] But beyond these purely physical meanings, the word has taken on other connotations, suggesting the pervasive spirit of a school, or its genius loci, as embodied in its architecture and grounds" (Turner, 1984, p. 4). The 'language' of campuses has varied from one century to another and one place to another. Initially, the American higher educational system was influenced by the British ideal where students and teachers lived and studied together. In turn, this layout of universities was modeled on monasteries where all main functionalities were present and formed 'the campus' (Scotto, 2014). Since the 1980s, these campuses have also been increasingly shown and performed in the practice of 'campus tours' for key external stakeholders, in particular, prospective students and their parents, sponsors, and tourists (Magolda, 2000). The importance of tours of physical spaces to 'impress' visitors has long been established (Kuh, 
1990; Braxton and Clendon, 2001; Atkinson and Hammersley, 1994). For centuries, showing a place, emphasizing its history, its beauty, its technical or aesthetic performance, has been a way to legitimate an organization and its leaders. Historical examples abound. In particular, in the 17th century, the French King Louis the XIV wrote a text entitled "How to show gardens of Versailles, by Louis the XIV" ("La manière de montrer les jardins de Versailles par Louis XIV”). It has, however, taken on a special urgency and criticality for many organizations, given the multiplicity of stakeholders they face and the diversity of institutional logics that may govern them.

University campuses and campus tours thus provide a suitable case for studying the intersection between materiality, legitimation practices and institutional logics. First, they constitute events that are highly ritualized and done by many universities worldwide. This implies that it is an established practice and creates a potential for comparison and contrast. Furthermore, campus tours are occasions in which organizations encounter potential stakeholders, and the management of legitimacy is at stake. Their situated nature in a material context was also a determining factor for choosing campus tours as a vehicle to study legitimation efforts through communication practices. Lastly, for the last 30 years or so, higher education, particularly in the US, has been characterized by a transformation where market mechanisms and industry standards have seeped into the field and challenged the legitimating ideas of universities as social institutions. Gumport (2000), followed by other scholars (Carnoy and Rhoten, 2002; Kondakci and Van den Broeck, 2009), made the case that higher education in the US has become shaped by two competing logics - the industry (or market) logic and the social logic. (Table 1 describes the key values, root metaphors, key stakeholders and key criteria for legitimacy as prescribed by the different logics). These logics are field-level logics and may in turn be expressed and enacted in multiple ways 'on the ground' (McPherson and Sauder, 2013). The legitimation practices of campus tours become 
one way (among others) in which organizational members seek to manifest, negotiate, and reject adherence to the logics of the field. A campus tour can assert the openness of a university and its social orientation (which involves a sense of non-profitability and a general access to knowledge), but also emphasize the innovative, business orientation (which draws on the market logic with an ambition for excellence, selection and knowledge for the elite of society). Narratives can be used to emphasize, for example, success stories of alumni who are now economic leaders, involvement of students in charities, etc.; these narratives would invoke very different artifacts (e.g. big lecture hall, small class rooms, luxurious entry hall, comfortable rooms, dormitories, etc.).

\begin{tabular}{|l|l|l|}
\hline \multicolumn{1}{|c|}{ LOGICS } & $\begin{array}{l}\text { INDUSTRY OR MARKET } \\
\text { LOGIC }\end{array}$ & \multicolumn{1}{|c|}{ SOCIAL LOGIC } \\
\hline Key values & $\begin{array}{l}\text { Performance, functionality, } \\
\text { differentiation, competitive } \\
\text { advantage }\end{array}$ & $\begin{array}{l}\text { Justice, equality, } \\
\text { accessibility, diversity }\end{array}$ \\
\hline Root metaphors & Machines & Tradition \\
\hline $\begin{array}{l}\text { Key stakeholders involved in } \\
\text { the logic }\end{array}$ & Customers & Citizens \\
\hline Key criteria for legitimacy & $\begin{array}{l}\text { Efficiency, tangibility, value, } \\
\text { innovation }\end{array}$ & $\begin{array}{l}\text { Sustainable development, } \\
\text { equality }\end{array}$ \\
\hline
\end{tabular}

Table 1. Key characteristics of the two logics in higher education (adapted from Gumport, 2000)

The social logic implies that knowledge is viewed as something that all citizens have the right to and it emphasizes the free or affordable access to universities as well as inclusivity and diversity. It emphasizes how universities interact and contribute to the broader social environment and its culture, norms, history, and techniques as well as socially-pressing issues such as equality and ethics. The social logic also views universities as historical institutions, where certain myths and traditions are seen as important.

The market or industry logic sees universities more from a business-like perspective. When the market logic is enacted, individuals pay attention to the functional characteristics of the 
university and its practical, immediate values (e.g. buildings, classrooms, ITs, sports stadiums, and amphitheaters) as well as their sophistication, exhaustiveness, or modernity. Individuals also put forward the qualities of the campus, its education and competitive advantage, drawing differentiation on an economic and/or strategic rhetoric, and how they sustain the value customers will be willing to pay for.

\section{Data collection methods}

Our data collection was based on participant observations of real life campus tours in order to collect rich and contextual data. Our sample was based on multiple observations at nine different universities in the US and Europe performed between April 2013 and July 2014. The campus tours lasted for approximately 60-180 minutes. Notes were taken during and right after the tours, which were extended to include details we did not have time to elaborate on during the actual tour. Our observations followed an observation guideline (see appendix 1). The guideline was elaborated after a first exploratory tour at McGill University in April 2013. The dimensions it includes derived from cross-discussions among co-authors. We identified dimensions likely to describe the modalities, context, focus, objectives and process of the tours.

Each tour generated between 5-10 pages of typed notes and in total, we gathered more than 60 pages of notes. We followed a disciplined approach to our field-note taking and always expanded and finalized the notes within the same day of the tour. This was to ensure that the notes would include a maximum of detail and be as accurate as possible. Numerous photos were also taken at each site in order to remember details of the context, such as certain artifacts or the arrangement of spaces.

In addition to observational data we also collected archival data, such as campus maps, articles, books, and information about the history of the campuses and the universities. This 
information (detailed in Table 2 below) enabled us to understand more about the background and to place the narrative told during the tour in a broader context. The maps were also used to get a clear understanding for the sites of each campus that the tours presented, as well as obscured.

To systematize our data collection, we applied an observation guide (see appendix 1), which aligned with our interests in capturing the legitimation processes and how these were framed in a narrative anchored in space and materiality. Our real life experience of campus tours confirmed that multiple logics were at play in this setting, and that university members invoked the material context of the organization to promote and/or reconcile the logics on which the organization drew.

\begin{tabular}{|c|c|c|c|c|c|}
\hline $\begin{array}{l}\text { Universities } \\
\text { explored }\end{array}$ & $\begin{array}{c}\text { Period of } \\
\text { observation }\end{array}$ & Collected data & $\begin{array}{c}\text { Key spaces } \\
\text { involved in the } \\
\text { campus tour }\end{array}$ & $\begin{array}{c}\text { Main artifacts } \\
\text { shown }\end{array}$ & Tour schedule \\
\hline $\begin{array}{l}\text { Mc Gill } \\
\text { university, } \\
\text { Montreal, } \\
\text { Canada }\end{array}$ & $\begin{array}{l}\text { April } 2013 \\
\text { Participation } \\
\text { in two } \\
\text { campus tours }\end{array}$ & $\begin{array}{l}\text { Participant observation of two campus tours } \\
\text { (around } 1 \mathrm{~h} \text { each) } \\
\text { Pictures (12), maps, leaflets, screen } \\
\text { printings of the website } \\
\text { Articles and books about the history of } \\
\text { McGill University }\end{array}$ & $\begin{array}{l}\text { One campus (of } \\
\text { two) }\end{array}$ & Buildings, statues & $\begin{array}{l}1 \text { hour } \\
\text { (Two per day) } \\
\text { On-line } \\
\text { registration }\end{array}$ \\
\hline $\begin{array}{l}\text { La } \\
\text { Sorbonne, } \\
\text { Paris, } \\
\text { France }\end{array}$ & $\begin{array}{l}\text { September } \\
\text { and October } \\
2013\end{array}$ & $\begin{array}{l}\text { Participant observation of two campus tours } \\
\text { Maps, leaflets, screen-printings of the } \\
\text { website. } \\
\text { Articles and books about the history of La } \\
\text { Sorbonne and the Université de Paris } \\
\text { Pictures (9) }\end{array}$ & $\begin{array}{l}\text { A main, } \\
\text { historical } \\
\text { building } \\
\text { (Maison } \\
\text { Sorbonne) }\end{array}$ & $\begin{array}{l}\text { Buildings, big } \\
\text { historical lecture } \\
\text { hall, paintings, } \\
\text { status }\end{array}$ & $\begin{array}{l}\text { Two hours } \\
\text { (by appointment } \\
\text { from Monday to } \\
\text { Friday and on } \\
\text { one Saturday } \\
\text { per month) } \\
\text { Registration by } \\
\text { email }\end{array}$ \\
\hline $\begin{array}{l}\text { Stanford } \\
\text { University, } \\
\text { Stanford, } \\
\text { CA, USA }\end{array}$ & $\begin{array}{l}\text { September } \\
\text { and October } \\
2013\end{array}$ & $\begin{array}{l}\text { Participant observation of one campus tour } \\
\text { Pictures (24), maps, leaflets, books and } \\
\text { articles about the history of Stanford } \\
\text { university } \\
\text { Pictures (19) }\end{array}$ & $\begin{array}{l}\text { The oldest parts } \\
\text { of campus }\end{array}$ & $\begin{array}{l}\text { Sports facilities, } \\
\text { oldest buildings, } \\
\text { big lecture halls, } \\
\text { buildings named } \\
\text { after famous people } \\
\text { or where famous } \\
\text { researchers have } \\
\text { worked or are } \\
\text { working. }\end{array}$ & $\begin{array}{l}11 / 2 \text { hour (twice } \\
\text { a day, year } \\
\text { round, open to } \\
\text { all). No } \\
\text { registration } \\
\text { needed. }\end{array}$ \\
\hline $\begin{array}{l}\text { UC } \\
\text { Berkeley, } \\
\text { Berkeley, } \\
\text { CA, USA }\end{array}$ & $\begin{array}{l}\text { November } \\
2013\end{array}$ & $\begin{array}{l}\text { Participant observation of one campus tour } \\
\text { Maps, leaflets, screen-printings of the } \\
\text { website. } \\
\text { Articles about the history of UC Berkeley } \\
\text { Pictures (11) }\end{array}$ & $\begin{array}{l}\text { The oldest parts } \\
\text { of campus }\end{array}$ & $\begin{array}{l}\text { Sports facilities, } \\
\text { library, old } \\
\text { buildings and } \\
\text { artifacts }\end{array}$ & $\begin{array}{l}11 / 2 \text { hour (on } \\
\text { specific days } \\
\text { year round). } \\
\text { Registration via } \\
\text { online } \\
\text { registration } \\
\text { system required. }\end{array}$ \\
\hline $\begin{array}{l}\text { Vienna } \\
\text { University } \\
\text { of } \\
\text { Economics } \\
\text { and } \\
\text { Business, }\end{array}$ & May 2014 & $\begin{array}{l}\text { Participant observation of one campus tour } \\
\text { Maps, leaflets, screen printings of the } \\
\text { website } \\
\text { Pictures (12) and videos (3) }\end{array}$ & New campus & $\begin{array}{l}\text { Modern new } \\
\text { buildings (library, } \\
\text { student center) }\end{array}$ & $\begin{array}{l}45 \text { minutes } \\
\text { (upon request) }\end{array}$ \\
\hline
\end{tabular}




\begin{tabular}{|c|c|c|c|c|c|}
\hline $\begin{array}{l}\text { Vienna, } \\
\text { Austria }\end{array}$ & & & & & \\
\hline $\begin{array}{l}\text { London } \\
\text { School of } \\
\text { Economics } \\
\text { \& Political } \\
\text { Sciences, } \\
\text { London, UK }\end{array}$ & June 2014 & $\begin{array}{l}\text { Participant observation of one campus tour } \\
\text { Maps, leaflets (e.g. 'LSE explorer'), screen } \\
\text { printings of the website } \\
\text { Pictures (18) }\end{array}$ & Entire campus & $\begin{array}{l}\text { Old building, the } \\
\text { Shaw library, } \\
\text { fourth floor } \\
\text { restaurant, student } \\
\text { service center, } \\
\text { library, Lincoln's } \\
\text { inn fields, new } \\
\text { academic buildings, } \\
\text { Saw Swee Hock } \\
\text { student center, } \\
\text { Peacock theater, the } \\
\text { towers, Clement } \\
\text { house, LSE Garrick }\end{array}$ & $\begin{array}{l}\text { Annual tours. } \\
\text { Self-guided } \\
\text { tours (with big } \\
\text { map LSE } \\
\text { explorer). Maps } \\
\text { and } \\
\text { recommendation } \\
\text { to do the tour } \\
\text { offered at the } \\
\text { students' center. } \\
\text { Duration: } 11 / 2 \\
\text { hour on average } \\
\text { to cover the } 12 \\
\text { recommended } \\
\text { spots. }\end{array}$ \\
\hline $\begin{array}{l}\text { San Jose } \\
\text { State } \\
\text { University, } \\
\text { San Jose, } \\
\text { CA, USA }\end{array}$ & July 2014 & $\begin{array}{l}\text { Participant observation of one campus tour. } \\
\text { Maps, leaflets provided at check in. } \\
\text { Pictures (10) }\end{array}$ & Entire campus & 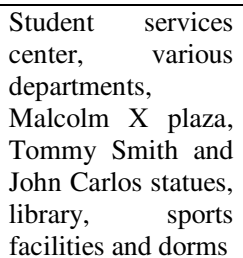 & $\begin{array}{l}\text { Close to daily } \\
\text { tours year } \\
\text { round. Duration: } \\
1 \text { hour. } \\
\text { Registration via } \\
\text { online system } \\
\text { required. }\end{array}$ \\
\hline $\begin{array}{l}\text { San } \\
\text { Francisco } \\
\text { State } \\
\text { University, } \\
\text { San } \\
\text { Francisco, } \\
\text { CA, USA }\end{array}$ & July 2014 & $\begin{array}{l}\text { Participant observation of one campus tour. } \\
\text { Maps, leaflets provided at check in. } \\
\text { Pictures (8) }\end{array}$ & Entire campus & $\begin{array}{lr}\text { Student } & \text { services } \\
\text { center, } & \text { various } \\
\text { departments, } & \\
\text { student } & \text { union, } \\
\text { library, } & \text { science } \\
\text { buildings } & \end{array}$ & $\begin{array}{l}\text { Close to daily } \\
\text { tours year } \\
\text { round. Duration: } \\
1 \text { hour. } \\
\text { Registration via } \\
\text { online system } \\
\text { required. }\end{array}$ \\
\hline
\end{tabular}

Table 2. Overview of data collection. Analysis

Our analysis of the qualitative data started with an open coding of the data set, in particular our field notes (Charmaz, 2006). We coded our data in a grounded way (Corbin and Strauss, 1990) by completing open and axial coding of our memos (see appendix 2), which was followed by a discussion and comparison of the emerging codes. At this stage, what emerged as particularly salient was the various ways in which the buildings, spaces, and artifacts of the universities were invoked during the tour in ways that clearly suggested an adherence or rejection of particular institutional logics.

In a second round, after iterating with the literature and de Certeau (1984) in particular, we coded the data again with the ambition to understand more clearly the various forms of practices that organizational members undertook to create links between materiality and logics during the tours. This led to a more fine-grained categorization of various forms of de 
Certeau's (1984) 'synecdoches' and 'asyndetons. (See Table 3 below for an overview of our coding scheme). 


\begin{tabular}{|c|c|c|c|c|c|}
\hline First order codes & Empirical examples & $\begin{array}{l}\text { Examples of } \\
\text { logics connoted }\end{array}$ & $\begin{array}{l}\text { Theoretical } \\
\text { constructs }\end{array}$ & Axial coding & Propositions \\
\hline $\begin{array}{l}\text { Isolated artifacts } \\
\text { pointed out as } \\
\text { descriptive of the } \\
\text { university }\end{array}$ & $\begin{array}{l}\text { Berkeley: Presentation of a dinosaur } \\
\text { skeleton intertwined with a story of } \\
\text { how students and professors } \\
\text { cooperated in crafting the dinosaur, } \\
\text { which was delivered in thousands of } \\
\text { pieces. }\end{array}$ & $\begin{array}{l}\text { Social logic - } \\
\text { Emphasis on } \\
\text { learning, equal } \\
\text { opportunities, } \\
\text { student support } \\
\text { and involvement } \\
\text { and the role of } \\
\text { the university in } \\
\text { society. }\end{array}$ & $\begin{array}{l}\text { Legitimacy } \\
\text { claims based } \\
\text { on object- } \\
\text { focused } \\
\text { synecdoches }\end{array}$ & \multirow[t]{3}{*}{$\begin{array}{l}\text { Drawing on } \\
\text { materiality to } \\
\text { infer } \\
\text { adherence to } \\
\text { particular } \\
\text { logics }\end{array}$} & \multirow{3}{*}{$\begin{array}{l}\text { Proposition } 1 \text { : } \\
\text { Practices, } \\
\text { performed in the } \\
\text { material context } \\
\text { of walking } \\
\text { campus tours, can } \\
\text { rely upon } \\
\text { "legitimizing } \\
\text { synecdoches" that } \\
\text { highlight certain } \\
\text { parts of a campus } \\
\text { to legitimize the } \\
\text { entire } \\
\text { organization. } \\
\text { Proposition } \\
\text { The material } \\
\text { practice } \\
\text { walking allows } \\
\text { organizational } \\
\text { members to make } \\
\text { legitimacy claims } \\
\text { by invoking } \\
\text { 'reconciling } \\
\text { synecdoches' that } \\
\text { invoke space to } \\
\text { mediate potential } \\
\text { conflict between } \\
\text { logics. ins } \\
\text { Proposition } \\
\text { The material } \\
\text { practice } \\
\text { walking allows } \\
\text { organizational } \\
\text { members to make } \\
\text { legitimacy claims } \\
\text { synecdoches'. }\end{array}$} \\
\hline $\begin{array}{l}\text { Unique spaces } \\
\text { pointed out as } \\
\text { descriptive of the } \\
\text { university }\end{array}$ & $\begin{array}{l}\text { Stanford University: The guide } \\
\text { points to the Bill Gates building and } \\
\text { says that this is where Google started } \\
\text { and that Google's server was located } \\
\text { in a Lego box in that building, hence } \\
\text { the colors of the Google logo, he } \\
\text { says. He then points to the Hewlett } \\
\text { and the Packard buildings, two } \\
\text { buildings that are built in a much } \\
\text { more modern style. He says that both } \\
\text { Hewlett and Packard went to } \\
\text { Stanford and that they got together in } \\
\text { the so-called HP garage and started } \\
\text { their company. }\end{array}$ & $\begin{array}{l}\text { Market logic - } \\
\text { emphasis on the } \\
\text { unique and } \\
\text { successful } \\
\text { innovations that } \\
\text { the university } \\
\text { has fostered }\end{array}$ & $\begin{array}{l}\text { Legitimacy } \\
\text { claims based } \\
\text { on spatial } \\
\text { synecdoches }\end{array}$ & & \\
\hline $\begin{array}{l}\text { Territories pointed } \\
\text { out and used as an } \\
\text { entryway to an } \\
\text { unrelated } \\
\text { description of the } \\
\text { university }\end{array}$ & $\begin{array}{l}\text { Stanford University: The tour arrives } \\
\text { to the area in front of the main quad, } \\
\text { the oval, which is where the Palm } \\
\text { drive leads up to the university. It is a } \\
\text { big open space and the Palm Drive, a } \\
\text { street with palm trees planted on each } \\
\text { side, can be seen the whole way } \\
\text { down to Palo Alto. It is a stretch of } \\
\text { approximately } 1 \mathrm{~km} \text {. The guide talks } \\
\text { a bit about the education at Stanford. } \\
\text { He says that as a prospective student, } \\
\text { you apply to Stanford and not to } \\
\text { specific courses, and once you are } \\
\text { accepted you choose from } 3 \text { different } \\
\text { undergraduate schools. He says he } \\
\text { now wants to talk about } \\
\text { transportation and mentions that } \\
\text { there are more bikes than people on } \\
\text { campus, but that he prefers to walk } \\
\text { everywhere. He says that some } \\
\text { people use skateboards. }\end{array}$ & $\begin{array}{l}\text { Social logic - } \\
\text { emphasis on the } \\
\text { accessibility of } \\
\text { the university } \\
\text { and } \\
\text { environmental } \\
\text { friendliness of } \\
\text { alternative } \\
\text { transportation. }\end{array}$ & $\begin{array}{l}\text { Legitimacy } \\
\text { claims based } \\
\text { on territorial } \\
\text { synecdoches }\end{array}$ & & \\
\hline $\begin{array}{l}\text { Avoidance of } \\
\text { places }\end{array}$ & $\begin{array}{l}\text { McGill University: We move on to a } \\
\text { corridor linking two buildings and } \\
\text { enter into the anthropology } \\
\text { department, which is avoided (we do } \\
\text { not go straight and avoid a liminal } \\
\text { corridor) and is not commented by } \\
\text { our guide. This is another period of } \\
\text { silence. }\end{array}$ & $\begin{array}{l}\text { Avoidance of } \\
\text { undesirable } \\
\text { places and/or } \\
\text { departments that } \\
\text { do not fit into } \\
\text { the narrative and } \\
\text { the desired } \\
\text { symbolic. }\end{array}$ & $\begin{array}{l}\text { Legitimacy } \\
\text { claims based } \\
\text { on focused } \\
\text { asyndetons }\end{array}$ & $\begin{array}{l}\text { Avoiding or } \\
\text { downplaying } \\
\text { materiality to } \\
\text { show } \\
\text { adherence to } \\
\text { or refrain } \\
\text { from } \\
\text { particular }\end{array}$ & $\begin{array}{l}\text { Proposition } 4 \text { : } \\
\text { The material } \\
\text { practice of } \\
\text { walking allows } \\
\text { organizational } \\
\text { members to make } \\
\text { legitimacy claims } \\
\text { by invoking }\end{array}$ \\
\hline $\begin{array}{l}\text { Transition } \\
\text { between places }\end{array}$ & $\begin{array}{l}\text { San Jose State University: On the } \\
\text { way from the office of student } \\
\text { affairs, where the tour started, we } \\
\text { pass several anonymous grey cement } \\
\text { buildings. The guide does not } \\
\text { comment on these and instead } \\
\text { engages in a narrative that explains } \\
\text { the various forms of support } \\
\text { available to students of the } \\
\text { university. }\end{array}$ & $\begin{array}{l}\text { Certain } \\
\text { transitional } \\
\text { spaces are } \\
\text { passed, yet } \\
\text { neglected since } \\
\text { they do not fit } \\
\text { into the narrative } \\
\text { and the desired } \\
\text { symbolic. }\end{array}$ & $\begin{array}{l}\text { Legitimacy } \\
\text { claims based } \\
\text { on } \\
\text { transitional } \\
\text { asyndetons }\end{array}$ & & $\begin{array}{l}\text { 'concealing } \\
\text { asyndetons' }\end{array}$ \\
\hline $\begin{array}{l}\text { Hidden places } \\
\text { pointed out as } \\
\text { descriptive of the } \\
\text { university }\end{array}$ & $\begin{array}{l}\text { LSE: The guide emphasizes that the } \\
\text { access to the New Academic } \\
\text { Building is restricted to LSE staff } \\
\text { and students, creating a sense of } \\
\text { prestige and exclusivity. }\end{array}$ & $\begin{array}{l}\text { Market logic - } \\
\text { emphasizing that } \\
\text { the school is } \\
\text { only for a } \\
\text { selected few }\end{array}$ & $\begin{array}{l}\text { Legitimacy } \\
\text { claims based } \\
\text { on imaginary } \\
\text { asyndetons }\end{array}$ & & $\begin{array}{l}\text { Proposition } 5: \\
\text { The material } \\
\text { practice of } \\
\text { walking allows } \\
\text { organizational } \\
\text { members to make }\end{array}$ \\
\hline
\end{tabular}




\begin{tabular}{|c|c|c|c|c|}
\hline $\begin{array}{lr}\text { Making } & \text { the } \\
\text { audience } & \\
\text { experience } & \text { a } \\
\text { particular } & \\
\text { atmosphere } & \end{array}$ & $\begin{array}{l}\text { San Jose State University: The tour } \\
\text { walks inside one of the buildings } \\
\text { through a long hallway. It seems to } \\
\text { be a way to show one of the oldest } \\
\text { and most historical buildings and it is } \\
\text { a pretty nice building with an old feel } \\
\text { to it. It signals 'old and traditional } \\
\text { university' which most other } \\
\text { buildings definitely do not. The } \\
\text { guide does not make any comments } \\
\text { when inside. }\end{array}$ & $\begin{array}{l}\text { Social logic - } \\
\text { The history and } \\
\text { embeddedness } \\
\text { in a long history } \\
\text { and tradition }\end{array}$ & $\begin{array}{l}\text { Legitimacy } \\
\text { claims based } \\
\text { on ambient } \\
\text { asyndetons }\end{array}$ & $\begin{array}{l}\text { legitimacy claims } \\
\text { by invoking } \\
\text { 'evoking } \\
\text { asyndetons' }\end{array}$ \\
\hline
\end{tabular}

Table 3. Overview of coding scheme.

\section{Creating links between legitimacy claims and space through the walked campus tour}

In this section, we build and justify four propositions related to the relationship between legitimizing practices (in particular, those focused on asyndetons and synecdoches), materiality and institutional logics emerging from our data.

Proposition 1 - Practices, performed in the material context of walking campus tours, can rely upon "legitimizing synecdoches" that highlight certain parts of a campus expected to legitimize the entire organization.

In a context of institutional complexity with multiple logics (Friedland and Alford, 1991; Kraatz \& Block, 2008), which impose conflicting demands and pressures on organizations and their members (Jarzabkowski et al. 2013; Greenwood et al. 2010), walking was a way for organizational members to invoke artifacts and narratives to mobilize and emphasize the adherence to particular logics. Particularly, it was a way to create "legitimizing synecdoches". We define legitimizing synecdoches as the walked practice of invoking particular places and artifacts in legitimacy claims.

This was visible in all of the campus tours that we observed. In some cases, a campus tour seemed to draw on mainly one particular logic in its legitimizing synechdoches. In other cases, multiple logics were blended with equal emphasis. In yet other cases there was a 
dominant logic with additional elements from other logics. Independent of one of the several logics being promoted, it was clear that universities engaged in a practice of carefully choosing only a selected few out of many possible spaces and artifacts to promote during the campus tour. For example, at San Jose State University (SJSU), which adhered mostly to the social logic, the starting point of the tour took place at the Student services center, which was largely emphasized. The center was invoked to tell a narrative of all the various types of services that students could receive for free, such as counseling, course advice and preadmission services, the guide acknowledging that everyone can have a hard time at some point during their studies. The fact that the tour started at the Student services center gave the audience a sense of accessibility to these services, as well as established credibility to these claims. Throughout the tour, the social logic of a university that is accessible and open to everyone continued to be emphasized by pointing out particular spaces that were carefully selected. For example, when arriving at the building in which the bookstore was located, the guide, pointing at the bookstore, emphasized that books can be purchased on credit allowing for more payment flexibility for students with financial difficulties. Another example is how two statues of Afro-American men located at the 'Malcolm X plaza' - 'Tommie Smith and John Carlos', former students known for their historic demonstration as medalists in the 1968 Olympic games, are invoked in a narrative about the university's focus on diversity. The guide vividly describes the statues in detail and how Smith's raised right black-gloved fist represents black power. The scarf around the neck represents pride and the box he is carrying with an olive sapling represents peace. The other statue is of Carlos, with his raised left blackgloved fist representing unity in America, and the beads around his neck signifying the lynching suffered by Black people, the guide explains. She further emphasizes that students successfully fought for the statue to be placed at the center of campus instead of being located 
at the sport's center, which was the original idea. Diversity is important to the campus, the Latin tour guide says with emphasis.

A contrasting example of a university that drew largely on the market logic, putting forward the competitive and functional elements of the campus, was Stanford. For example, when the tour arrived in front of the main quad, the guide, who was also a student of the university, engaged in a narrative that emphasized the vastness of the campus, stating that it is the second largest in the world after University of Moscow. The large auditoriums were also pointed out as places that had hosted numerous famous speakers such as Hillary Clinton, Al Gore, and the Dalai Lama. Thus, these particular places came to be invoked in the campus tour as something larger, illustrative of a broad claim of superiority and elitism along the lines of the market logic. Another example of amplification is when the tour passed the computer science buildings named after Bill Gates, and the Hewlett and Packard buildings, where the guide points out that the original server of Google is still in the basement of one of the buildings on campus; and that the founders - Sergey Brin and Larry Page - had studied at Stanford. These particular buildings were invoked to make legitimacy claims that again drew on the market logic, stating the innovativeness and the many companies that had spurred from the university.

As yet another illustration of how walking was a way for organizational members to invoke artifacts and narratives to mobilize and emphasize the adherence to particular logics, the University of Sorbonne drew largely on historical artifacts and spaces to craft legitimacy claims drawing on the social logic. Historical artifacts have a very strong symbolic power through their longevity and can be invoked and put forward when more market-oriented, competitive and functional resources are lacking. In the case of Sorbonne University, the working spaces of former Professors Pierre and Marie Curie (who attended the university in the beginning of the 1900s) were pointed out. Also, the grandiose scene of the amphitheater 
was pointed out and interwoven with a narrative revolving around Marie Curie and her historical keynote speech which was held there, which was an event often categorized as the turning point in the history of the role of women in French academia. Thus, these examples show how historical artifacts are invoked in the practice of campus tours as a resource to bring up equality and diversity, connoting the social logic. It could also be argued that this emphasis on historical spaces and artifacts was a way to compensate for a lack of infrastructure, or a 'real' campus to show (as Sorbonne is spread out in several different buildings throughout Paris and does not have a campus in the American sense).

The examples above illustrate a practice that, on one hand, was about selectivity of a few among many possible spaces and artifacts that could have been shown during the campus tour, and on the other, an emphasis and amplification of these particular spaces and artifacts. This resonates with de Certeau's (1984) notion of synecdoche and we therefore refer to this as 'legitimizing synecdoches' due to the connection that we establish with legitimacy. For synecdoches to work, walking is clearly imperative. During a guided tour, the selectivity and exaggeration done through the invocation of synecdoches become less problematic than in other forms of communication. This is because, even if not emphasized, many of the spaces and artifacts are oftentimes still visible. Thus, the problem of making 'false' claims is less present in this form compared to other forms of communication where distortion, exaggeration and selectivity, the making of 'more' (de Certeau, 1984) would be seen as false advertising and potentially threaten legitimacy. When organizations of today make legitimacy claims drawing on the social logic to claim sustainability, for example, it is often received with suspicion and skepticism among stakeholders (Gond, 2010; Butler, 2011). However, by pointing out material manifestations of the logic by employing legitimizing synecdoches, legitimacy claims may become more credible. The walked format, in particular, allows the 
audience to gain a lived experience of a large part of a campus, yet only a few spaces and artifacts are chosen to become interwoven into the narrative of legitimacy claims.

Proposition 2 - The material practice of walking allows organizational members to make legitimacy claims by drawing on 'reconciling synecdoches' that invoke space to mediate potential conflict between logics.

Synecdoches are not only useful as a way to make legitimacy claims drawing on one particular logic. "Reconciling synechdoches" refer to how spaces were invoked to alleviate potential conflict between logics, as a form of strategy to make legitimacy claims compatible despite invoking competing logics simultaneously. This definition extends Swan et al's. (2010, p. 1334) view of individuals crafting compatibility out of seemingly incompatible logics. They stated that "despite creating a patchwork of seemingly contradictory modes of working", individuals can blend logics "artfully and selectively [...] to lend legitimacy to their practices". It also alludes to Pache and Santos (2013) argument that individuals can respond to competing logics by attempting to integrate them. We show that materiality has an important role in this practice.

A first illustrative example of how the campus tour managed to alleviate a conflict between logics was when the tour guide on the Stanford campus tour invoked the church to show the university's adherence to ethics (connoting the social logic) rather than being a religious institution (hence avoiding connoting a religious logic, which does not characterize today's higher education, but was largely present and guided the activities of universities a century or so ago). This maneuver was done by spending a relatively long period of time of the tour in the church, where participants were instructed to tour it in silence, particularly focusing on the inscribed messages on its walls. A text about the church states that these inscriptions were selected by Mrs. Stanford and represented her religious faith. However, before entering the 
church, the tour guide framed them as being ethical guidelines to students rather than religious ones. At the same time, the fact that the tour did indeed spend a considerable amount of time in the church, providing the opportunity for the audience to live the space and project their own interpretations of it, signaled an importance attributed to religious institutions, and hence dissolved a possible tension between the two logics. In this example, the church was invoked in the pedestrian figure of a synecdoche to signify a 'more' that expanded beyond the most obvious connotation of a religious logic. Yet again, this example shows how synecdoches are employed to exaggerate and emphasize the adherence to particular logics. In addition, it also demonstrates that through possibilities that are offered by walking in a space, by experiencing it, synecdoches invite multiple interpretations of a space that allow for mediation of conflicts between logics. Through the walked campus tour, which is simultaneously a narration and a movement in space, multiple interpretations and experiences are invited that would be much harder to navigate in other forms of communication.

A second example from the campus tours at Stanford was the attempt to balance the market logic that they drew largely upon (as described under proposition 1), with elements of the social logic. For example, the campus tour guide at Stanford repeatedly pointed out recycling bins, construction sites (framed as building more environmentally-friendly buildings), electric bus shuttles, the large number of bikes on campus, and the nearby train station (alluding to the accessibility to campus via train to all). In this way, seemingly mundane artifacts and spaces were invoked as synecdoches, i.e. manifestations and materializations of the social logic.

Another example is drawn from the campus tour of VU Vienna. This campus is very recent, and was designed by numerous famous architects and ended up being highly expensive $(\approx 500$ million Euros). During the tour, the great architecture was continuously emphasized by pointing out the various buildings, explaining the thoughts behind each of them and the respective architects. Thus, each building came to represent a logic of the market, where 
universities compete for their students not only based on the degrees and knowledge they provide, but also on their aesthetics and functional and infrastructural aspects of the campus. Simultaneously, the tour guide used synecdoches to make 'more' out of the natural materials chosen in the new buildings, the natural light and the so called 'lakes' on campus, as well as the closeness to a vast natural park, which altogether aimed at connoting a social logic where nature and environmental values are more salient. Thus, this practice apparently reconciled incompatible logics by invoking various material aspects of the campus.

The London School of Economics tour also illustrates this point, creating both an adherence to the social and market logics. Starting the tour with the Old building gave a sense of longevity and social importance to a relatively young institution (compared to Oxford or Cambridge universities). Moving then to recent, modern and grandiose places of the campus (Student service center, Lincoln's Inn fields acquired in 2013 and the New academic building) in contrast gave a sense of the global competitiveness, expansion and growth of LSE, adhering to a market-logic of business-like growth.

An final example of this practice of making the incompatible compatible is the campus tour at McGill, which aimed to reconcile the competing social and market logics by prioritizing its immersion and interaction with its local context of Montreal and the Quebec area (social logic), while simultaneously emphasizing that it is a university that competes on the global arena for the most talented students (market logic). This is a longstanding challenge for McGill as it at times sees protesters at its doorsteps who bemoan that its courses are offered in English. As a way to resolve this conflict, the tour guide invoked several synecdoches to make 'more' out of artifacts in the storytelling during the campus tour. First, a long period of time was spent in front of the tomb of the founder McGill, referring to his English origins, making the tomb a manifestation of the European impregnation of the university, hence exaggerating the presence of the tomb to become a symbol for something larger - the 
adherence to a market logic that acknowledges internationalization and globalization, while also acknowledging its history and longevity and thus drawing on the social logic.

Thus, synecdoches allow for multiple interpretations and reconciliation of logics since they can be framed as multifaceted. To reconcile multiple logics in practices of legitimation is a complex exercise. The examples above show how the very flexibility of space itself (de Vaujany and Vaast, 2014) and how it is simultaneously walked and narrated, can be helpful in the management of tensions. Thus, this practice was possible due to the interpretive flexibility of materiality, which implies that they can be invoked to put forward various logics, i.e. an artifact does not signify a logic in itself, but it is the context in which it is invoked and the narrative surrounding it that creates its meaning in relation to institutional logics. This flexibility creates possibilities for actors to 'play' with artifacts and craft legitimation practices that are coherent, but may simultaneously put forward multiple and competing logics. This practice resonates with previous studies that have found that organizational members can employ 'interpretive flexibility' and 'strategic ambiguity' to frame artifacts in various ways in order to cater to the needs and agendas of various stakeholders (Orlikowski, 1992; Barley et al. 2012).

Proposition 3 - The material practice of walking allows organizational members to make legitimacy claims by invoking 'concealing asyndetons' in order to make legitimacy claims.

Our empirical data also showed that a common practice during campus tours was to hide or avoid (deliberately) particular spaces and artifacts. "Conceiling asyndetons" implies that the walked practice allows for an avoidance of undesirable spaces and artifacts that do not fit the desired legitimacy claims. The tour at Sorbonne university is one example where this strategy was implemented to make legitimacy claims. During the campus tour, there was much emphasis placed on how the space relates to the republic (laic) governance system of the state, 
emphasizing that the university is a social institution and part of the broader society. Several artifacts were used as synecdoches of this governance system, such as the statue of the Marianne, which is a symbol of the French republic. However, in order to craft this adherence to the social logic, the campus tour was also forced to invoke a strategy of asyndetons - of avoidance of certain artifacts, such as the Fleur de Lys, that were symbolic of the historical monarchic governance system.

In the case of San Jose State University, we also found the use of the legitimizing strategy of asyndetons. For example, the tour guide points out the business school building, which is a pretty tall and fairly new building. The surrounding concrete buildings from the 60 s or so are not mentioned and instead the audience's attention is directed to another modern building that has just been constructed. This is clearly a strategy of concealing and downplaying in order to make legitimacy claims.

In summary, the guided walk of campus tours allows for a subtle way for organizations to select and disregard particular places and artifacts that they consider undesirable and that would risk undermining legitimacy. While the audience has the experience of a transparency of the campus that is laid out for them, the asyndetons are invoked to hide or downplay particular spaces or artifacts.

Proposition 4 - The material practice of walking allows organizational members to make legitimacy claims by invoking 'evoking asyndetons' in order to make legitimacy claims

Finally, our findings also showed that organizational members at times employed a strategy to make legitimacy claims that involved the creation of imagery or particular atmospheres during the walked practice. We define this as "evoking asyndetons". Here, the campus tour guide could describe, vividly, a space or artifact that would be out of sight to the audience, yet making legitimacy claims based on this invisible materiality. This involved a great deal of 
storytelling as well as the audience's own imagination. It also required more trust compared to the pointing out of artifacts and spaces that were before the eyes of the beholders. One example of this was during the campus tour at Berkeley, where the tour guide pointed to a building hidden behind a grove and explained that it hosts the College of national resources, which does research on environmental sciences, nutrition and political management. This building, the guide emphasized, also hosts the first undergraduate library in the US. This was clearly a legitimacy claim that drew on the social logic. However, the materiality that was invoked to support this claim remained invisible, yet had an important role. Another example is drawn from the tour at San Jose State University, where the tour guide brought the audience through a long and beautiful hallway that was atypical of the architecture of the rest of the buildings on campus and which was located in an older building. The guide did not talk much during the passing in the hallway, yet this passage seemed to feature an important symbolism, namely that the university has a long history and traditions worthy of an old institution. Here, the storytelling was left to the audience's imagination and by instantiating an atmosphere that was historical, it could be expected that the audience would equal their experience with that of touring an older, more ancient institution. Thus, the particular atmosphere that the hallway provided was a way to connote the social logic by emphasizing, through an atmosphere created by movement in a particular space, the (not quite so) long history of the university and its roots.

\section{Discussion}

Our propositions shed light on how campus tours provide embodied experiences of the intangible activities of universities. They constitute opportunities for stakeholders to get to know an organization through sensory experiences such as seeing, touching, smelling. Since many contemporary service-oriented organizations, such as universities, engage in complex, abstract and immaterial activities, such embodied experiences of the organization's 
physicality and performing activities take on a heightened importance (de Vaujany and Vaast, 2014, 2014). Gieryn (2002, p. 40) argued that materiality, such as buildings, provides an "institutional reality to the intangible such as academic disciplines or specialties" and they help "convert the abstraction of [academic] discipline into something more palpable, stable, and enduring". That legitimation practices and logics are linked is well known. However, what institutional scholars have not yet greatly examined is the way in which artifacts are used to show adherence to particular logics and how these can be mobilized in legitimation practices in ways aimed at promoting legitimacy. Research on legitimation has so far remained at a symbolic and discursive level and artifacts have mostly been absent. This paper attempts to address this gap in the literature. Our propositions outline the different roles that artifacts and spaces take on as they are invoked in legitimacy claims in the walked campus tour.

First, legitimation practices based on walking can reflexively select and combine different institutional logics. Through the invocation of artifacts into narratives, an organization chooses to put forward certain claims while concealing others. Spaces and artifacts provide a material reality to the desired logics and claims and are thus powerful, concrete tools in legitimation practices. Thus, we allude to how material practices direct attention and inform meaning-making among stakeholders. This is an important distinction from the more common preoccupation regarding how values shape practices.

Second, materiality can also be used to resolve conflict and altering meanings due to the interpretive flexibility of materiality, and the playfulness or artfulness of organizational members (Swan et al, 2010).

Third, for the same reason of interpretive flexibility, invoking materiality allows organizational members to downplay institutional logics and create alternative, credible 
legitimation practices. If universities lack resources or infrastructures to make market-related claims for functionality, for instance, campus tours may highlight, instead, the historical features of buildings and present narratives that emphasize other sources of meaning and legitimation. Thus, the walked practice allows not only for putting forward, but also concealing and hiding undesirable materialities that may risk undermining the desired legitimacy claims. This practice of 'concealing' is important and has thus far been largely ignored in studies on the how individuals enact logics on the ground. Even in institutional studies that promote the visual, there has been a neglect of that which is not seen (Meyer et al, 2013)

Fourth, materiality and particular spaces and sites allows for the creation of experiences that foster the imagination among stakeholders to, for example, historical or prospective times. It is more about an aesthetic springboard for invoking logics, rather than a cognitive one, and it cannot easily be translated into language (Langer, 1957). Aesthetics are often referred to as the 'non-rational of organizational life' (Warren, 2008). The aesthetic experience is triggered by material things and it is also a highly embodied, sensory mode of being in the world (Warren, 2008). While aesthetics has been largely ignored in institutional theory, our findings open up a new line of inquiry that promotes a need for a deeper understanding how aesthetics are linked to institutional logics as well as how this 'non-rational' medium can be used to make legitimacy claims.

This research adds to the emerging field of understanding the micro-foundations of institutional theory, where scholars have started to show an interest for how institutions are enacted in the everyday practices of individuals (McPherson and Sauder's, 2013; Smets and Jarzabkowski, 2013), as well as the role of materiality (Jones et al. 2013) and visuality (Meyer et al, 2013; Puyou and Quattrone, 2018) in altering, disrupting, or maintaining institutional logics. Materiality has been conceptualized as an actor in several theoretical fields, in 
particular research on organizational space, Science and Technology Studies, Actor Network theories and some evolutionist views of organizations (Jones et al. 2013; de Vaujany and Mitev, 2013). Also, in the literature about organizational space and spatial practices, the spatial and material dimensions of societies and more recently, organizations, have been largely explored (Gagliardi, 1992; Kornberger and Clegg, 2005; Dale and Burrell, 2008; Yanow and Marrewjik, 2010). Mainly in continuation of Lefebvre (1991) and the spatiomaterial aspects of seminal social studies (e.g. Marx, Engels and Lenin, 1974; Bourdieu, 1972; Giddens, 1984, 1985), but also Merleau-Ponty $(1945,1961)$ and his view of experience or American pragmatism, it shows that organizations and organizing processes are interpenetrated by their spatial, temporal and material environment (Dale, 2005; Pitz et al, 2017; de Vaujany et al, 2018). Finally, it illustrates the 'materiality turn' that has grown increasingly popular in IS and organization studies and posits practices as socio-material, and materiality as constitutive of everyday life (Barad 2003; Latour 2005; Suchman 2007; Orlikowski, 2007; Pozzebon et al, 2018)). Materiality, in this view, "is not an incidental or intermittent aspect of organizational life; it is integral to it" Orlikowski, 2007, p. 1436). Nonetheless, this stream of literature has rarely investigated the relationship between spatial practices and legitimacy claims (Wasserman and Freckle, 2011; de Vaujany and Vast, 2014). Our tentative theory integrates these two streams and suggests the various ways in which materiality is invoked in legitimacy claims drawing on various institutional logics. Thus, materiality constitutes an important part of the 'tool box' of cultural elements (Swidler, 1986) that organizational members may invoke to construct legitimacy.

This research also brings attention to mobility, i.e. walking, as a practice worthy of including in institutional analyses. By drawing on de Certeau's work, we zoomed in on a particular aspect of the micro-foundations of institutions that had not yet been examined, namely the important role of moving in instantiating the materiality of organizations and in 
asserting particular legitimacy claims. While practices have started to become an important focus for institutional theorists, there is still little effort put into theorizing about the constitution of practices. Practices are oftentimes used as a synonym to micro-level actions, but the elements of practices remain largely blackboxed. By acknowledging mobility as an important facet of practices, we start to unpack this concept. We find support for this among an emerging number of scholars in methodology, who have started to acknowledge the uniqueness and empirical value of walking practices (Anderson, 2004; Evans and Jones, 2011). However, there is still a dearth of research on the role of embodied mobility in and between organizations. Our research illustrates how the practice of walking provides visual experiences as well as embodied and material matter to institutions. Movement may be experienced merely as a visual flow (e.g. a passenger sitting on a train in motion). Yet, walking in the streets and spaces of cities, campuses or organizations allows for multi-sensory stimulation of the surrounding environment (Adams \& Guy, 2007), which provides "an immediacy as well as a kinaesthetic rhythm” (Middleton, 2009 in Evans and Jones, 2011, p. 850) that a focus on the visual alone does not capture. Thus, walking is not only about a transfer from A to B, but an occasion where the surrounding materiality is instantiated and brought to life through asyndetons and synechdoches (de Certeau, 1980). Walking practices relate to, transfer and transform institutional logics, and give life to the material matter of organizations. While we agree that the recent preoccupation with the role of the visual in institutional theory is an interesting way to advance the inclusion of materiality (Meyer et al, 2013), our focus on movement underlines its limitations in accounting for the more embodied experiences that materiality provides when 'walked and lived'.

\section{Conclusions}

This paper has examined how the walking practices of campus tours invoke materiality to make legitimacy claims and provided five tentative propositions that constitute the stepping- 
stone for an emerging theory on the links between materiality and legitimacy. It is a first attempt to shed light on the importance of incorporating mobility and materiality into any analysis of legitimation and institutional dynamics. In qualitative research, the challenge of representativeness is always lingering. In this work, in particular, we had no way of ascertaining that the tours we followed at particular universities were representative of the other tours we could have followed over the academic year. Moreover, our study was focused on a subset of European and North American campuses, which provides a highly westernized view on the phenomenon.

For future research, there is promise in contrasting campus tours to other tour contexts (e.g. corporate tours or museum tours) as this may reveal different instantiations of institutional logics. We also urge scholars to continue to deepen the exploration of how visuality and materiality participate in micro-institutional dynamics and may embody organizational legitimacy. 


\section{References}

Adams, M., \& Guy, S. (2007). Editorial: Senses and the city. The senses and society, 2(2), 133-136.

Anderson, J. (2004). Talking whilst walking: a geographical archaeology of knowledge. Area, 36(3), 254-261.

Ashforth, B. E., \& Gibbs, B. W. (1990). The double-edge of organizational legitimation. Organization science, 1(2), 177-194.

Atkinson, P., \& Hammersley, M. (1994). Ethnography and participant observation. Handbook of qualitative research, 1(23), 248-261.

Augoyard, J.-F. (1979). Pas à pas. Essai sur le cheminement quotidien en milieu urbain.

Barad, K. (2003). Posthumanist performativity: Toward an understanding of how matter comes to matter. Signs, 28(3), 801-831.

Battilana, J., \& Dorado, S. (2010). Building sustainable hybrid organizations: The case of commercial microfinance organizations. Academy of Management Journal, 53(6), 1419-1440.

Binder, R. V. (2000). Testing object-oriented systems: models, patterns, and tools: Addison-Wesley Professional.

Bourdieu, P. (1972). Les stratégies matrimoniales dans le système de reproduction. Annales, 11051127.

Braxton, J. M., and McClendon, S. A. (2001). the fostering of social integration and retention through institutional practice. Journal of College Student Retention: Research, Theory and Practice, 3(1), 57-71.

Butler, J. (2011). Bodies that matter: On the discursive limits of sex: Taylor \& Francis.

Callon, M., \& Latour, B. (1986). Comment suivre les innovations? Clefs pour l'analyse sociotechnique. Prospective et santé, 36, 13-25.

Cetina, K. K. (1997). Sociality with objects. Theory, culture \& society, 14(4), 1-30.

Charmaz, K. (2006). Constructing grounded theory: A practical guide through qualitative research: London: Sage.

Corbin, J. M., \& Strauss, A. (1990). Grounded theory research: Procedures, canons, and evaluative criteria. Qualitative sociology, 13(1), 3-21.

Dale, K., and Burrell, G. (2008). The spaces of organization and the organization of space: Power, identity and materiality at work. Basingstoke: Palgrave Macmillan.

De Certeau, M. (1980). L'invention du quotidien, t. I, Arts de faire. Folio essais (éd. 1990).

de Certeau, M. (1984). Idéologie et diversité culturelle. Diversité Culturelle, Société Industrielle, Etat national. Paris: I'Harmattan.

de Vaujany, FX., Fomin, W., Haefliger, W. \& Lyytinen, K. (2018). Rules, Practices and Information Technology: A Trifecta of Organizational Regulation, Information Systems Research, https://doi.org/10.1287/isre.2017.0771

de Vaujany, X., \& Mitev, N. (Eds) (2013). Introduction: space in organization and sociomateriality. Materiality and space. Organizations, artefacts and practices, The Palgrave Macmillan, 1-24.

de Vaujany, F.-X., \& Vaast, E. (2014). Dual Iconographies And Legitimation Practices In Contemporary Organizations: A Tale Of The Former Nato Command Room. Materiality and Time: Historical Perspectives on Organizations, Artefacts and Practices, 33.

de Vaujany, F. X., \& Vaast, E. (2016). Matters of visuality in legitimation practices: Dual iconographies in a meeting room. Organization, 23(5), 763-790.

Dewey, J. (1939). Freedom and culture.

DiMaggio, P. J., \& Powell, W. W. (1983). The iron cage revisited: Institutional isomorphism and collective rationality in organizational fields. American sociological review, 147-160.

Elsbach, K. D. (1994). Managing organizational legitimacy in the California cattle industry: The construction and effectiveness of verbal accounts. Administrative science quarterly, 57-88. 
Fayard, A. L. (2012). Space matters, but how? Oxford: Oxford University Press.

Feldman, M. S., \& Orlikowski, W. J. (2011). Theorizing practice and practicing theory. Organization science, 22(5), 1240-1253.

Friedland, B. (2012). Control system design: an introduction to state-space methods: Courier Corporation.

Friedland, R., \& Alford, R. R. (1991). Bringing society back in: Symbols, practices and institutional contradictions.

Gagliardi, J. (1992). Dynamics of grinding brittle materials with coated abrasives. American Ceramic Society Bulletin, 71(11), 1641-1646.

Gherardi, E. F. X. (2012). Comprendre et accompagner le développement de l'enseignement bilingue en Corse. L'enseignement des langues locales: institutions, méthodes, idéologies, Actes des quatrièmes journées des droits linguistiques.

Giddens, A. (1984). The constitution of society: introduction of the theory of strcuturation: University of California Press.

Giddens, A. (1985). A contemporary critique of historical materialism: the nation-state and viloence (Vol. 2): University of California Press.

Gieryn, T. F. (2002). What buildings do. Theory and society, 31(1), 35-74.

Golant, B. D., \& Sillince, J. A. (2007). The constitution of organizational legitimacy: A narrative perspective. Organization studies, 28(8), 1149-1167.

Gond, J.-P. (2010). Gérer la performance sociétale de l'entreprise: Vuibert.

Goodrick, E., \& Reay, T. (2011). Constellations of Institutional Logics Changes in the Professional Work of Pharmacists. Work and Occupations, 38(3), 372-416.

Jarzabkowski, P., Spee, A. P., \& Smets, M. (2013). Material artifacts: Practices for doing strategy with 'stuff'. European management journal, 31(1), 41-54.

Jarzabkowski, P., Smets, M., Bednarek, R., Burke, G., \& Spee, P. 2013. Institutional ambidexterity: Leveraging institutional complexity in practice. Research in the Sociology of Organizations, 39: 3761.

Jones, C., Livne-Tarandach, R., \& Balachandra, L. (2010). Rhetoric that wins clients: Entrepreneurial firms use of institutional logics when competing for resources. Research in the Sociology of Work, 21, $183-218$.

Jones, C., Boxenbaum, E. \& Anthony, C. (2013). The immaterial of the material in institutional logics. Research in the Sociology of Organizations, special issue on Institutional Logics in Action, vol 39

Elsevier Health Sciences.

kornberger, M., and Clegg, S. R. (2004). Bringing space back in: organizing the generative building. Organization studies, 25(7), 1095-1114.

Kraatz, M. S., \& Block, E. S. (2008). Organizational implications of institutional pluralism. The Sage handbook of organizational institutionalism, 840.

Kuh, G. D. (1990). Assessing student culture. New Directions for Institutional Research, 1990(68), 4760.

Langer, S. (1957). Philosophy in a new key. Milton Keynes: Open University Press.

Latour, B. (1987). Science in action: How to follow scientists and engineers through society: Harvard university press.

Latour, B. (2005). La science en action: introduction à la sociologie des sciences: La Découverte/Poche.

Lefebvre, H. (1991). The production of space (Vol. 142): Oxford Blackwell.

Lounsbury, M., \& Glynn, M. A. (2001). Cultural entrepreneurship: Stories, legitimacy, and the acquisition of resources. Strategic Management Journal, 22(6-7), 545-564. 
Maclean, M., Harvey, C., \& Chia, R. (2012). Sensemaking, storytelling and the legitimization of elite business careers. Human Relations, 65(1), 17-40.

Magolda, B. (2005). MB (2000). Teaching to promote intellectual and personal maturity: incorporating students' worldviews and identities into the learning process.

Marx, K., Engels, F., and Lenin, V.I. (1974). On historical materialism: a collection. New York: International Publishers.

McPherson, C. M., \& Sauder, M. (2013). Logics in Action Managing Institutional Complexity in a Drug Court. Administrative science quarterly, 0001839213486447.

Monteiro, P., \& Nicolini, D. (2014). Recovering Materiality in Institutional Work Prizes as an Assemblage of Human and Material Entities. Journal of Management Inquiry, 1056492614546221.

Ocasio, W. (1997). Towards an attention-based view of the firm. Strategic Management Journal, 18(S1), 187-206.

Oliver, C. (1991). Strategic responses to institutional processes. Academy of management review, 16(1), 145-179.

Orlikowski, W. J. (1992). The duality of technology: Rethinking the concept of technology in organizations. Organization science, 3(3), 398-427.

Orlikowski, W. J. (2007). Sociomaterial practices: Exploring technology at work. Organization studies, 28(9), 1435-1448.

Pache, A.-C., \& Santos, F. 2013a. Embedded in hybrid contexts: How individuals in organizations respond to competing institutional logics. Research in the Sociology of Organizations, 39: 3-35.

Pickering, J. M., \& King, J. L. (1995). Hardwiring weak ties: Interorganizational computer-mediated communication, occupational communities, and organizational change. Organization science, 6(4), 479-486.

Pinch, T. (2008). Technology and institutions: Living in a material world. Theory and Society, 37(5), 461-483.

Pinon, L. (2008). La culture scientifique à Rome au miroir des livres (1527-1650): apports et limites de l'approche bibliographique. Rome et la science moderne, 1000-1034.

Pittz, T. G., Boje, D. M., Intindola, M. L., \& Nicholson, S. (2017). 'COPE'ing with institutional pressures: a reintroduction of pragmatism to the study of organisations. International Journal of Management Concepts and Philosophy, 10(2), 113-129.

Puyou, F.R. and Quattrone, P. (2018). The Visual and Material Dimensions of Legitimacy: Accounting and the Search for Socie-ties, Organization Studies, https://doi.org/10.1177/0170840618765013

Rafaeli, A., \& Vilnai-Yavetz, I. (2004). Emotion as a connection of physical artifacts and organizations. Organization science, 15(6), 671-686.

Reay, T., \& Hinings, C. R. (2009). Managing the rivalry of competing institutional logics. Organization studies, 30(6), 629-652.

Reckwitz, A. (2002). Toward a theory of social practices a development in culturalist theorizing. European journal of social theory, 5(2), 243-263.

Rose, G., \& Tolia-Kelly, D. P. (2012). Visuality/materiality: Images, objects and practices: Ashgate Publishing, Ltd.

Sandberg, J., \& Dall'Alba, G. (2009). Returning to practice anew: A life-world perspective. Organization studies, 30(12), 1349-1368.

Schatzki, T. R. (2001). Practice mind-ed orders.

Scott, P. (1995). The meanings of mass higher education: McGraw-Hill International.

Scotto, C. (2014). The principles of campus conception: a spatical and organizational genalogy. what knowledge can we use from a historical study in order to analyze the design processes of a new campus. In F. X. de Vaujany, Mitev, N., Laniray, P., and Vaast, E. (Eds), Materiality and time (Ed.), (pp. 204-224). London: Palgrave. 
Smets, M., Morris, T., \& Greenwood, R. (2012). From practice to field: A multilevel model of practicedriven institutional change. Academy of Management Journal, 55(4), 877-904.

Smets, M., \& Jarzabkowski, P. (2013). Reconstructing institutional complexity in practice: A relational model of institutional work and complexity. Human Relations, 66(10), 1279-1309.

Suchman, L. (1995). Making work visible. Communications of the ACM, 38(9), 56-ff.

Suchman, L. (2007). Human-machine reconfigurations: Plans and situated actions: Cambridge University Press.

Suddaby, R. (2010). Challenges for institutional theory. Journal of Management Inquiry, 19(1), 14-20.

Suddaby, R., \& Greenwood, R. (2005). Rhetorical strategies of legitimacy. Administrative science quarterly, 50(1), 35-67.

Swidler, A. (1986). Culture in action: Symbols and strategies. American sociological review, 273-286.

Taylor, S., \& Spicer, A. (2007). Time for space: A narrative review of research on organizational spaces. International Journal of Management Reviews, 9(4), 325-346.

Thornton, P. H. (2004). Markets from culture: Institutional logics and organizational decisions in higher education publishing: Stanford University Press.

Thornton, P. H., Ocasio, W., \& Lounsbury, M. (2012). The institutional logics perspective: A new approach to culture, structure, and process: Oxford University Press.

Warren, S. (2008). Empirical challenges in organizational aesthetics research: Towards a sensual methodology. Organization Studies, 29(4), 559-580.

Yanow, D., Van Marrewijk, A., \& Yanow, D. (2010). Giving voice to space: academic practices and the material world. Organizational Spaces-Rematerializing the Workaday World, 139-158. 


\section{APPENDICES}

\section{Appendix 1. Observation guideline of campus tours}

The guide aimed at capturing the main verbal narrative that was told, as well as how this narrative related to places and artifacts during the tour.

- $\quad$ D1: How is the tour communicated? Our focus here was the tools, actors, organizational structures, etc. involved in the practice of legitimation.

D2: Where is the meeting point?

D3: Who is guiding the tour? What is the profile of the guide?

D4: What is the narrative told during the tour? Are there specific aspects that are recurrently emphasized?

D5: What is the trajectory of the tour? What were the main sites visited/artifacts shown? What is the appearance and aesthetics of these spots and artifacts?

D6: Are there sites of the campus that are excluded from the tour? If so, which parts?

D7: How are the artifacts and spaces enacted in front of visitors? 
Appendix 2. The distribution of institutional codes (market versus social) for each tour

\begin{tabular}{|l|l|l|l|}
\hline \multicolumn{1}{|c|}{ Tour } & $\begin{array}{l}\text { Number of } \\
\text { sequences } \\
\text { identified }\end{array}$ & Market logic & Social logic \\
\hline $\begin{array}{l}\text { Université } \\
\text { La } \\
\text { Sorbonne }\end{array}$ & 6 & 1 & 8 \\
\hline $\begin{array}{l}\text { McGill } \\
\text { University }\end{array}$ & 4 & 2 & 3 \\
\hline $\begin{array}{l}\text { Stanford } \\
\text { University }\end{array}$ & 9 & 7 & 4 \\
\hline $\begin{array}{l}\text { San } \\
\text { Francisco } \\
\text { State } \\
\text { University }\end{array}$ & 10 & 3 & 12 \\
\hline $\begin{array}{l}\text { UC } \\
\text { Berkeley }\end{array}$ & 9 & 3 & 10 \\
\hline $\begin{array}{l}\text { Vienna } \\
\text { University }\end{array}$ & 5 & 5 & 2 \\
\hline LSE & 12 & 8 & 4 \\
\hline $\begin{array}{l}\text { San Jose } \\
\text { State } \\
\text { University }\end{array}$ & 8 & 1 & 7 \\
\hline
\end{tabular}

